\title{
OPTIMIZING THE CAPITAL STRUCTURE OF THE U.S. SMALL BUSINESSES IN THE MIDST OF THE FINANCIAL CRISES - THE CASE OF CALIFORNIA
}

\section{ROBERT RUMIŃSKI}

University of Szczecin, Faculty of Management and Economics of Services, POLAND

e-mail: mail@robertruminski.com

RECEIVED

ACCEPTED

JEL

CLASSIFICATION

KEYWORDS

ABSTRACT
6 November 2018

3 December 2018

G32, L53, 016

change in capital structure, entrepreneurial finance, small business, financial crises

Finding the optimal enterprise capital structure and understanding the access of firms to finance, particularly in the process of financing small enterprises have been of great importance. Small enterprises face numerous problems in accessing external funds. They tend to be bank dependent. Obtaining the optimal capital structure is challenging - especially in the midst of financial crises. This paper is concerned with the capital structure in the U.S. small enterprises and its tendencies towards fluctuation. The data and statistical analysis derived from the empirical research and empirical study that was done in California are discussed. The paper presents the literature review on the capital structure and its theories. Moreover, there is a presentation and analysis of the association between particular empirical research questions regarding the capital structure, financing preferences and other important qualitative factors.

\section{Introduction}

Small businesses face acute problems in accessing funds. There has been a large interest in understanding the access of firms to finance, particularly in the process of financing small enterprises and startups. The adequate capital structure of small enterprises is of crucial importance. An economic slowdown (and in particular the one resulting from a financial crisis) provides numerous stimuli for financial intermediaries to tighten the cooperation 
with their clients (enterprises), be it as a way of reducing the informational asymmetry to a minimum and to ensure a better quality monitoring. In the course of reduced economic growth, companies are more likely to hold a loan at one intermediary. During the time of incertitude, all the entities of the financial market seek opportunities for stable and sustainable development. Looking for a golden solution to the problems occurring in the financial system, intermediaries (particularly during the time of crisis) turn their attention to continuous and sustainable growth, and they pay a far greater attention to establishing long-term and close relationships with clients. As one of the world's largest economies, the United States is one of the most attractive business locations in the world. Despite a relative deterioration in its macroeconomic environment and in the availability of financing caused by the financial crises, it remains an indispensable business destination with a long-running reputation for a favorable business climate.

\section{Litepature review}

There has been no coherent theory and the share of external capital depends on the relation between the enterprise profitability and the market interest rate. If the market interest rate is lower than the enterprise profitability, then it is advisable to take advantage of using external capital, and make use of a financial leverage. Unprofitable and riskier firms consistently use greater leverage. Smaller enterprises have a lower probability of survival (greater risk of failure). It is usually reflected in less favorable terms of debt financing, including higher interest rates to compensate for the higher costs of information collection. Financial intermediaries assess small enterprises as being inherently more risky. Experienced bankers or other specialized financial intermediaries can assess the risks associated with new ventures (startups) better than inexperienced insiders like young, inexperienced entrepreneurs and managers. Lending to small business is more likely to be based on collateral. Therefore, lending may not be based on the expected return, but on the access to collateral. On the other hand, collateral reduces "moral hazard" and "adverse selection." Small businesses lacking an access to high quality collateral suffer from credit rationing (OECD, 1997, p. 18). The abovementioned small business financial weaknesses heavily influence their capital structure. In case a debt financing is not available, the fundamental question arises: is an enterprise owner willing to share power and dilute his/her ownership in exchange for equity capital raised from external investors? (Rumiński, 2005, pp. 8-9).

The theories of capital structure have been changing over the years - starting with the theory of a perfectly competitive market to the most modern ones - specifying the hierarchy of the sources of financing or information asymmetry. The capital structure decision constitutes one of the most fundamental issues in corporate finance. As mentioned above, it considers the choice between debt and equity, which is an essential issue of every enterprise's financial policy. Defined as gearing or leverage, it can generally be described as the share proportion (relative amount of capital) between the two main categories of financing sources - equity capital and debt - used in financing the enterprises' activity. It is crucial to select such a capital structure that minimizes the costs of capital and maximizes the value of an enterprise. A majority of researchers recognize that it is a relation of long-term debt to equity, without accounting for short-term debt. Such a view is presented by, inter alia, Duliniec (2007) and Jerzemowska (1999). According to them, a capital structure is a part of financing structure, encompassing the structure of liabilities. Its development needs to aim at maximizing enterprise value (Bielawska, 2009, p. 80).

A number of rules and principles are formulated in literature, aiming to facilitate the fulfillment of the main objectives of an enterprise, inter alia, maximizing its market value at a given risk level. T. Jajuga and T. Słoński (1998, p. 208) define an enterprise capital structure narrowly, stating that it is a combination of a given company's 
equity and external capital. It excludes the possibility of the optimization of the total capital financing of an enterprise. The final capital structure is a result of the impact of a large number of various factors. Their variability, variety, and mutual ties make the actions aimed at determining an optimal capital structure to be searching for and getting closer to target values, rather than indicating one optimal value (Golej, Prędkiewicz, 2015, p. 181). The objectives of shaping a capital structure must comply with the enterprise management objectives.

The issue of an optimal mixture of financing is still contentious despite voluminous empirical evidence. Within the couple of decades, numerous studies have been conducted to test major competing theories. The theories of capital structure started to emerge in the 1950s. The development of those theories started with Durand's work in 1952, who, in his search for an optimal ratio of external capital to equity, introduced the concept of cost of capital. According to him, the cost of external capital was an interest on a contracted debt, whereas the cost of equity - the cost of an alternative equal to the rate, free of any risk increased by a risk premium (Gajdka, 2002, pp. 66-67).

A different perspective is presented by Modigliani and Miller (1958, pp. 261-297), whose theory refers to the relation between the company's debtand its own capital (equity) (Skowronek-Mielczarek, 2003, p. 37). The substitution theory focuses on the interchangeably applied equity and debt. Establishing their mutual proportions should bring about the optimum structure shape of the sources engaged. The pecking order and the trade-off theories provide two different points of view. They are formulated as specific models, and in real life situations they are easy to reject on a variety of dimensions. Both theories, often presented as unifying ones, have been illustrated in specific models with simplifying assumptions. F.E. Fama and K.R. French (2002), and M.J. Flannery and K.P. Rangan (2006) attempted to distinguish between the pecking order and the trade-off theories. The researchers found conflicting evidence - some supporting and some refuting each theory. The two theories of capital structure (pecking order and trade-off) together with the market-timing theory emerged as the best explanations for the capital structure decision. These three theories have become the finance profession's best explanations for the capital structure decision. Nonetheless, the first two are relevant for privately held enterprises that do not issue publicly traded securities. Whilst many studies tackle the capital structure decision, most empirical work considers large publicly listed firms (Degryse, Goeij, Kappert, 2012, p. 1).

\section{Method and resullts}

As far as the method and results are concerned there was an empirical research conducted in the U.S. in the years of 2009-2010. The survey was used in the study regarding the collaboration of the small business sector with institutions of financial intermediation. The questionnaire was addressed to the management of the small business sector operating in the selected key areas of Los Angeles and a study sample comprised of 550 active enterprises. The author conducted a statistical study in which the correlation analysis was performed between the different responses to particular questions included in the survey research. However, the author presented only those results that passed the test of significance $\mathrm{Chi}^{2}$. The level of significance was set at 0.05 . An economy in turmoil creates challenges to raise capital which constitutes the life blood of any business operation. The fear on the marketplace creates uncertainty. Due to a decrease in global demand, deceleration of industrial production rate, as well as a drop in the number of local and foreign business partners, it was a time of lower enterprise activity and higher business risk. Depending on the sector, enterprises experienced, with a varying degree, a decreased demand for their products and services, as well as the consequences of the market crash. During that period, many of the companies included in the study aimed only to survive and did not undertake any investment activities, thereby 
reducing the risk related to the use of borrowed capital. The risk of using debt by American small business was higher when predicting the reaction of banks and other financial institutions to sudden and adverse macroeconomic changes became harder. There is a close correlation between the problems of the financial sector resulting from the crisis and the financial condition and solvency of small business. Correct business risk estimation, evaluation of a company's financial condition, and its ability to prompt debt repayment from the point of view of a bank were greatly hindered.

Given the position in the business, and most preferred way (s) of financing business activity, it is noteworthy that the only group of people who pointed to the high-risk investments (venture capital/angel investors) is the category of owner/manager - over $6 \%$ of the respondents (6.06\%) - Table 1.

Table 1. Position in the business versus most preferred way(s) of financing business activity(\%)

\begin{tabular}{|c|c|c|c|c|c|c|c|c|c|c|c|c|}
\hline & 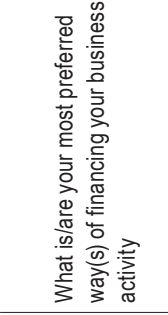 & 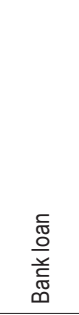 & 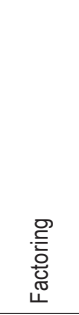 & 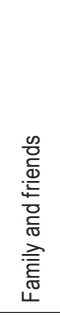 & 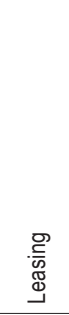 & 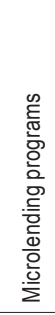 & 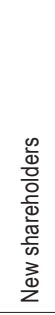 & 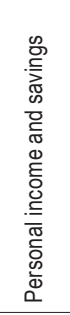 & 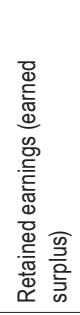 & 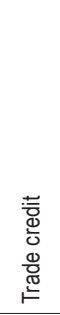 & 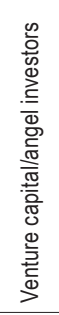 & $\begin{array}{l}\grave{\Phi} \\
\stackrel{ \pm}{ \pm}\end{array}$ \\
\hline \multirow{4}{*}{ 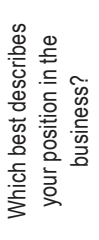 } & Owner/Manager & 42.42 & 36.36 & 3.03 & 18.18 & 0.00 & 9.09 & 45.45 & 39.39 & 0.00 & 6.06 & 12.12 \\
\hline & $\begin{array}{l}\text { Owner, but not } \\
\text { manager }\end{array}$ & 100.00 & 100.00 & 0.00 & 0.00 & 0.00 & 0.00 & 0.00 & 100.00 & 0.00 & 0.00 & 0.00 \\
\hline & $\begin{array}{l}\text { Manager, but not } \\
\text { owner }\end{array}$ & 50.00 & 50.00 & 0.00 & 0.00 & 0.00 & 0.00 & 50.00 & 50.00 & 0.00 & 0.00 & 0.00 \\
\hline & $\begin{array}{l}\text { Other (please } \\
\text { specify) }\end{array}$ & 100.00 & 100.00 & 0.00 & 0.00 & 0.00 & 0.00 & 0.00 & 0.00 & 0.00 & 0.00 & 0.00 \\
\hline
\end{tabular}

Source: own elaboration.

Providing such an answer only by owners and managers can attest to the fact that only functioning in a dual role (manager and owner of his/her own company) creates conditions to consider this type of risky forms of funding.

Comparing the period of economic activity and preferences on financing a business (Tables 2 and 3), it should be noted that companies which were established less than 6 months ago pointed to new shareholders and to retained earnings (earned surplus) $-100 \%$ of answers. This is understandable considering the fact that young companies have very limited funding opportunities. A high percentage of indications for venture capital/angel investors (100\%) occurred in the case of companies at least 6 months but less than 1 year old. This indicates that a large part of them is willing to develop their (innovative) activity using one of the unique forms of financing, which is well developed in California (mainly in the area of Silicon Valley).

A high percentage of the responses indicating a bank loan and factoring (100\%, respectively) appeared in the case of companies 4 and 5 years old. This is understandable due to the fact that banks base their analysis on the history of the operation, and the most effective cooperation (and exchange of information) between banks and companies takes place when companies have an established market position and demonstrate financial stability (a stable financial management). The high share of the indications on the above forms of financing is also the 
case with the older companies. Among some of them (ten years and older), financing also takes place in the form of a lease.

Table 2. The length of operating a business versus most preferred way(s) of financing (\%)

\begin{tabular}{|c|c|c|c|c|c|c|c|c|c|c|c|c|}
\hline & $\begin{array}{l}\text { What is/are your most preferred } \\
\text { way(s) of financing your business } \\
\text { activity }\end{array}$ & 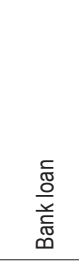 & 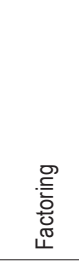 & 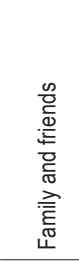 & 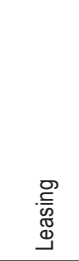 & 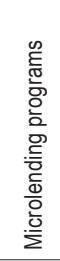 & 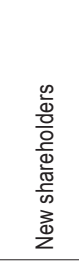 & 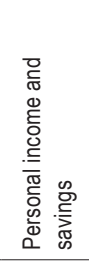 & 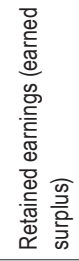 & 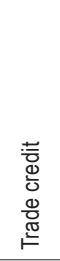 & 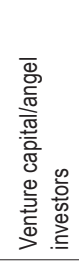 & 㐫 \\
\hline \multirow{10}{*}{ 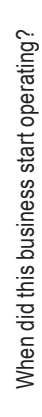 } & Less than 6 months ago & 0.00 & 0.00 & 0.00 & 0.00 & 0.00 & 100.00 & 0.00 & 100.00 & 0.00 & 0.00 & 0.00 \\
\hline & $\begin{array}{l}\text { At least } 6 \text { months but less than } \\
1 \text { year ago }\end{array}$ & 0.00 & 0.00 & 0.00 & 0.00 & 0.00 & 0.00 & 0.00 & 0.00 & 0.00 & 100.00 & 0.00 \\
\hline & 2 years ago & 0.00 & 0.00 & 0.00 & 0.00 & 0.00 & 33.33 & 66.67 & 33.33 & 0.00 & 33.33 & 0.00 \\
\hline & 3 years ago & 0.00 & 0.00 & 0.00 & 0.00 & 0.00 & 0.00 & 0.00 & 100.00 & 0.00 & 0.00 & 100.00 \\
\hline & 4 years ago & 100.00 & 100.00 & 0.00 & 0.00 & 0.00 & 50.00 & 0.00 & 0.00 & 0.00 & 0.00 & 0.00 \\
\hline & 5 years ago & 100.00 & 100.00 & 100.00 & 0.00 & 0.00 & 0.00 & 100.00 & 0.00 & 0.00 & 0.00 & 0.00 \\
\hline & 6 years ago & 0.00 & 0.00 & 0.00 & 0.00 & 0.00 & 0.00 & 100.00 & 100.00 & 0.00 & 0.00 & 0.00 \\
\hline & 8 years ago & 50.00 & 50.00 & 0.00 & 0.00 & 0.00 & 0.00 & 50.00 & 50.00 & 0.00 & 0.00 & 0.00 \\
\hline & 10 years ago & 100.00 & 100.00 & 0.00 & 100.00 & 0.00 & 0.00 & 0.00 & 0.00 & 0.00 & 0.00 & 0.00 \\
\hline & over 10 years ago & 52.17 & 43.48 & 4.35 & 21.74 & 0.00 & 0.00 & 43.48 & 39.13 & 0.00 & 0.00 & 13.04 \\
\hline
\end{tabular}

Source: own elaboration.

Table 3. Most preferred way(s) of financing by different industries represented by the respondents (\%)

\begin{tabular}{|c|c|c|c|c|c|c|c|c|c|c|c|c|}
\hline & $\begin{array}{l}\text { What is/are your most preferred way(s) } \\
\text { of financing your business activity }\end{array}$ & 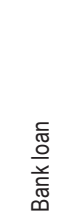 & 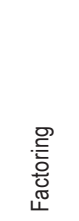 & 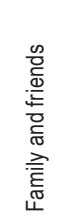 & 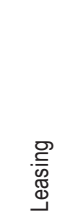 & 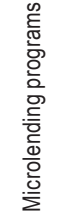 & 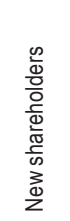 & 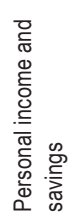 & 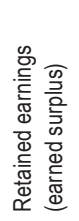 & 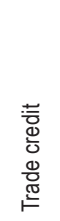 & 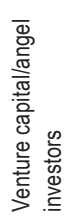 & $\begin{array}{l}\grave{\Phi} \\
\stackrel{ \pm}{ \pm}\end{array}$ \\
\hline \multirow{13}{*}{ 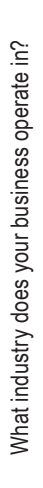 } & Accommodations or food service & 100.00 & 100.00 & 0.00 & 0.00 & 0.00 & 0.00 & 100.00 & 0.00 & 0.00 & 0.00 & 0.00 \\
\hline & Arts, entertainment, or recreation & 0.00 & 0.00 & 0.00 & 0.00 & 0.00 & 0.00 & 100.00 & 0.00 & 0.00 & 50.00 & 0.00 \\
\hline & Construction & 100.00 & 100.00 & 0.00 & 0.00 & 0.00 & 0.00 & 0.00 & 0.00 & 0.00 & 0.00 & 0.00 \\
\hline & Finance and insurance & 50.00 & 50.00 & 0.00 & 16.67 & 0.00 & 16.67 & 33.33 & 33.33 & 0.00 & 0.00 & 0.00 \\
\hline & Health care and social assistance & 100.00 & 100.00 & 0.00 & 0.00 & 0.00 & 0.00 & 0.00 & 100.00 & 0.00 & 0.00 & 0.00 \\
\hline & Information & 33.33 & 33.33 & 0.00 & 0.00 & 0.00 & 33.33 & 33.33 & 100.00 & 0.00 & 0.00 & 0.00 \\
\hline & Manufacturing, mining & 100.00 & 100.00 & 0.00 & 0.00 & 0.00 & 0.00 & 0.00 & 0.00 & 0.00 & 0.00 & 0.00 \\
\hline & Other service, incl. repair, personal care & 100.00 & 100.00 & 0.00 & 0.00 & 0.00 & 0.00 & 100.00 & 0.00 & 0.00 & 0.00 & 0.00 \\
\hline & Professional/scientific/technical services & 20.00 & 20.00 & 0.00 & 20.00 & 0.00 & 0.00 & 40.00 & 80.00 & 0.00 & 0.00 & 20.00 \\
\hline & Real estate and rental leasing & 100.00 & 100.00 & 0.00 & 0.00 & 0.00 & 0.00 & 0.00 & 0.00 & 0.00 & 0.00 & 0.00 \\
\hline & Retail trade & 33.33 & 33.33 & 16.67 & 33.33 & 0.00 & 0.00 & 50.00 & 33.33 & 0.00 & 0.00 & 33.33 \\
\hline & Wholesale trade & 100.00 & 100.00 & 0.00 & 100.00 & 0.00 & 0.00 & 0.00 & 0.00 & 0.00 & 0.00 & 0.00 \\
\hline & Other & 50.00 & 16.67 & 0.00 & 16.67 & 0.00 & 0.00 & 50.00 & 16.67 & 0.00 & 16.67 & 16.67 \\
\hline
\end{tabular}

Source: own elaboration. 
As far as the industry represented by the business is concerned, accommodations or food service highly prefers funding with bank loan, factoring, personal income, and savings (100\% of the answers, respectively) (Table 4). Arts, entertainment, or recreation pointed to personal income and savings (100\%). Construction sector pointed to bank loan and factoring (100\%, respectively). This probably results from the specificity of this sector which requires large amounts of long-term financing. Financial liquidity is difficult to maintain and further challenge is the adjustment of liabilities to a large group of counterparties. Finance and insurance, because of its specificity and broad industry expertise, showed interest in the majority of forms of financing as indicated in the survey, of which financing through a bank loan and factoring prevailed.

One of the most preferred forms of financing in different age groups is the bank loan and factoring (from 37.5 to $80 \%$ of the responses in the case of the first type of funding, and from 37.5 to $60 \%$ of the responses in the case of factoring) - Table 4.

Table 4. Preferred ways of financing by different age groups (\%)

\begin{tabular}{|c|c|c|c|c|c|c|c|c|c|c|c|c|}
\hline & $\begin{array}{l}\text { What is/are } \\
\text { your most pre- } \\
\text { ferred way(s) } \\
\text { of financing } \\
\text { your business } \\
\text { activity }\end{array}$ & 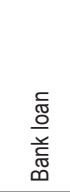 & 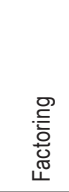 & 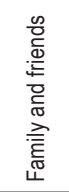 & 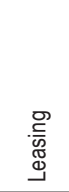 & 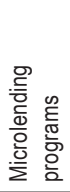 & 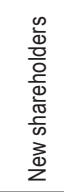 & 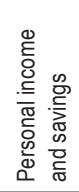 & 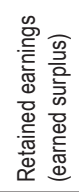 & 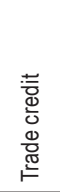 & 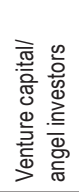 & 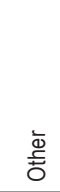 \\
\hline \multirow{5}{*}{ 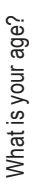 } & 25 to 34 years & 0.00 & 0.00 & 0.00 & 0.00 & 0.00 & 0.00 & 50.00 & 100.00 & 0.00 & 0.00 & 50.00 \\
\hline & 35 to 44 years & 77.50 & 37.50 & 0.00 & 0.00 & 0.00 & 12.50 & 37.50 & 50.00 & 0.00 & 25.00 & 0.00 \\
\hline & 45 to 54 years & 54.55 & 45.45 & 0.00 & 36.36 & 0.00 & 9.09 & 27.27 & 45.45 & 0.00 & 0.00 & 18.18 \\
\hline & 55 to 64 years & 44.44 & 44.44 & 11.11 & 22.22 & 0.00 & 11.11 & 44.44 & 22.22 & 0.00 & 0.00 & 0.00 \\
\hline & 64 and over & 80.00 & 60.00 & 0.00 & 0.00 & 0.00 & 0.00 & 60.00 & 40.00 & 0.00 & 0.00 & 0.00 \\
\hline
\end{tabular}

Source: own elaboration.

Between the responses to the question considering the following types of EQUITY, what percentage is in use by your business? (Angel Investor) and the responses to the question how would you rate your level of satisfaction with the financial services provided by your business primary financial institution?, there is a statistically significant negative strong correlation. Pearson's coefficient is -0.794423 (Table 5).

This means that the higher the level of funding for the company through Angel Investors, the lower the level of satisfaction with the financial services provided by the business primary financial institution.

This relationship may be due to the very different characteristics of angel financing and highly formalized financing with bank capital. The increase in funding from angel investors, and thus more intensive cooperation with the individual investor who has a high "market flexibility" in cooperation with the enterprise (usually a startup), results in a more critical assessment of the primary business financial institution by entrepreneurs. Banks have a high level of formalization and a limited degree of flexibility resulting from the use of procedures and the applicable prudent standards. It should be noted that the above correlation can also be interpreted in a different way, i.e., the higher the level of satisfaction with the financial services provided by the business primary financial institution, the lower the level of funding for the company by Angel Investors. This relationship seems to be reasonable. Such a situation can be justified by the high degree of satisfaction with the current funding, and, therefore the lack of the need to establish 
cooperation with Angel Investors. However, in order to draw meaningful conclusions, there should be an additional extended empirical study conducted on these issues.

Table 5. Pearson's coefficient - the association between question 45 and question 8

How would you rate your level of satisfaction with the financial services provided by your business primary financial institution?

Considering the following types of EQUITY, what percentage is currently in use by your business? (Angel Investor)

Source: own elaboration.

Between the responses to the question please indicate the percentage share of financial capital in use by your business (DEBT) and the responses to the question how important is LEASING in financing your business activity?, there is a strong negative correlation. Pearson's coefficient is -0.930040 (Table 6).

Table 6. Pearson's coefficient - the association between question 44 and question 36

How important is LEASING in financing your business activity?

Please indicate the percentage share of financial capital

in use by your business (DEBT)

$-0.93004$

Source: own elaboration.

So strong correlation between the answers to the above questions is surprising. The general conclusion might be that the higher the level of debt, the lower the significance of the lease. This fact (dependency) may be associated with the lack of opportunities for further debt financing (inability to lease). Nevertheless, in order to draw meaningful conclusions, an additional extended empirical study needs to be conducted.

\section{Conclusions}

The structure of business financing in the midst of the financial crises was fairly stable. Reduced loan activity of banks and deteriorated investment prospects that had emerged as a result of the economic slowdown since 2008 induced greater business conservatism. Apart from the greater use of their equity, the examined companies have significantly reduced their investment plans, and thus, apart from a drop in the use of bank loans, the use of alternative sources of financing dwindled as well, including sources such as quasi-banking institutions. The method of company financing was affected by the preference of enterprises themselves, but chiefly by the availability of particular sources of financing.

Bank loans have invariably remained the most popular external source of financing of American small business, typically short-term loans, whereas the smallest enterprises, i.e., micro-enterprises, take advantage of any external financing less frequently than other entities. As a rule, all forms of external financing are used to a greater extent by larger companies rather than by smaller ones, with the notable exception of the aforementioned loans from family and friends that are popular among the smallest enterprises. 
A significant portion of enterprises does not use any forms of external financing. Financing of operations exclusively from equity is very strongly correlated with a company size. For smaller entities, factors such as fear of debt and complicated procedures are far more important, and to a slightly lesser degree - the belief in their inability to serve such a debt along with their assumption of being unable to satisfy bank criteria. Thus, smaller enterprises demonstrate a far greater risk aversion, despite possessing insufficient equity to independently finance their operations and development. Enterprise size is a decisive factor in terms of searching for refundable funding and chances of obtaining it. Businesses more frequently apply for financing their current assets rather than investments - irrespectively of their size, while the chances of being granted the former are far greater. In the case of micro-enterprises, the chances of obtaining investment financing were only slightly increased by their high profitability.

\section{References}

Bielawska, A. (2009). Nowoczesne zarządzanie finansami przedsiębiorstwa. Warszawa: C.H. Beck.

Degryse, H., Goeij, P., Kappert, P. (2012). The impact of firm and industry characteristics on small firms' capital structure. Small Business Economics, 38 (4), 431-447. Retrieved from: https://link.springer.com/article/10.1007/s11187-010-9281-8.

Duliniec, A. (2007). Finansowanie przedsiębiorstwa. Warszawa: PWE.

Durand, D. (1952). Costs of Debt and Equity Funds for Business: Trends and Problems of Measurement. Conference on Research in Business Finance. National Bureau of Economic Research. Retrieved from: https://www.nber.org/chapters/c4790.pdf.

Fama, E.F., French, K.R. (2002). Testing Trade-Off and Pecking Order Predictions About Dividends and Debt. The Review of Financial Studies, 15 (1). Retrieved from: http://ecsocman.hse.ru/data/854/126/1231/fama_french_-_tradeoff_2002.pdf.

Flannery, M.J., Rangan, K.P. (2006). Partial Adjustment Toward Target Capital Structures. Journal of Financial Economics, 41. Retrieved from: http://lib.cufe.edu.cn/upload_files/other/4_20140512105606_12.pdf.

Gajdka, J. (2002). Teorie struktury kapitału i ich aplikacja w warunkach polskich. Łódź: Wydawnictwo Uniwersytetu Łódzkiego.

Golej, R., Prędkiewicz, K. (2015). Zarządzanie finansami przedsiębiorstwa. Wrocław: Wydawnictwo Marina.

Jajuga, T., Słoński, T. (1998). Finanse spółek. Długoterminowe decyzje inwestycyjne i finansowe. Wrocław: Wydawnictwo Akademii Ekonomicznej.

Jerzemowska, M. (1999). Kształtowanie struktury kapitału w spółkach akcyjnych. Warszawa, Retrieved from: https://repozytorium.amu. edu.pl/bitstream/10593/6900/1/22_Przegl_d\%20pi_miennictwa_B_Kolbusiewicz_J_Mizerka_287-291.pdf.

Modigliani, F., Miller, M. (1958). The Cost of Capital, Corporation Finance and the Theory of Investment. American Economic Review, 48 (3). Retrieved from: https://gvpesquisa.fgv.br/sites/gvpesquisa.fgv.br/files/arquivos/terra_-_the_cost_of_capital_corporation_ finance.pdf.

OECD (1997). Small businesses, job creation and growth: Facts, obstacles and best practices. Retrieved from: https:/www.oecd.org/ cfe/smes/2090740.pdf.

Rumiński, R. (2005). The analysis of the Polish financial capital market contribution to small and medium enterprises. Frankfurt, Germany: Master of Business Administration, Europa Universitat Viadrina.

Skowronek-Mielczarek, A. (2003). Wybory źródeł finansowania w małych i średnich przedsiębiorstwach. In E. Orechwa-Maliszewska, A. Kopczuk (eds.), Finansowe aspekty funkcjonowania małych i średnich przedsiębiorstw. Białystok: Wydawnictwo Wyższej Szkoły Finansów i Zarządzania w Białymstoku.

Cite this article aS:" Rumiński, R. (2018). Optimizing the capital structure of the U.S. small businesses in the midst of the financial crises - the case of California. European Journal of Service Management, 4 (28/1), 281-288. DOI: 10.18276/ejsm.2018.28/1-35. 